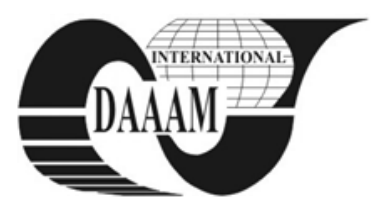

Annals of DAAAM for 2011 \& Proceedings of the 22nd International DAAAM Symposium, Volume 22, No. 1, ISSN 1726-9679 ISBN 978-3-901509-83-4, Editor B. Katalinic, Published by DAAAM International, Vienna, Austria, EU, 2011 Make Harmony between Technology and Nature, and Your Mind will Fly Free as a Bird Annals \& Proceedings of DAAAM International 2011

\title{
EXCELLENCE OF NONPROFIT ORGANIZATION
}

\author{
MARIC, I[vana]
}

\begin{abstract}
The issue of excellence is a significant problem in the global market and is equally challenging both for profit and nonprofit organizations. Public, profit and civil organizations are seeking the best ways to efficiently manage themselves in order to ensure the high quality of services and products. Every one of them wants to obtain a leading position in their field of work satisfying the customers and consumers. Simultaneously, they are trying to convey a public image of being socially responsible organizations with top business results. Nonprofit organizations have to focus on their mission and people, be aware of client needs and expectations and need to create new values and social innovations.
\end{abstract}

Key words: nonprofit organizations, excellence, mission-driven, management of nonprofit organization

\section{INTRODUCTION}

Nonprofit organizations make a significant contribution to society, emphasizing the importance of social versus economic values typically represented by for-profit organizations. The role of nonprofit organizations is to create a balance between the state and the market. Public and civil organizations should meet all the social, political and economic demands that citizens need or require.

Profit organizations are focused on making profit while nonprofit organizations are mission driven so consequently they have rather different direction of action, different primary values and their activities are differently oriented. Profit organizations start with concept of business logic (Wiijkström, 2009), are oriented towards some specific idea (goods or services, while on the other side nonprofit organizations start with a certain socially oriented mission and than form specific activities around people, volunteers and resources.

It is important to understand this completely different form and logic of these organizations through one basic question: What is our basic agenda / "la raison de l'existence"/ - a profit (some market value) or social mission (civil values or public good)?

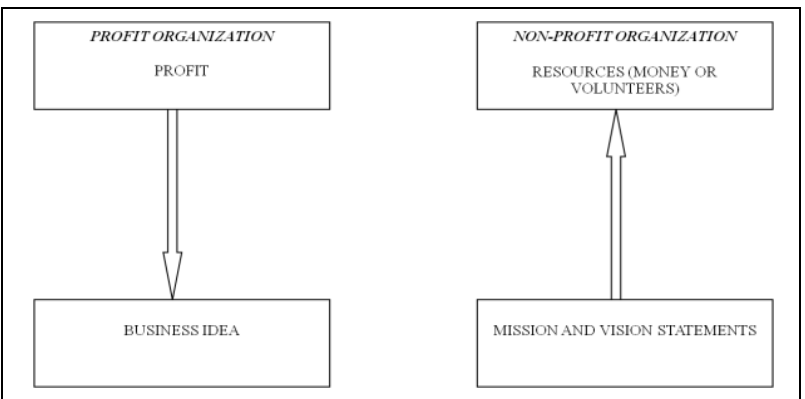

Fig.1. Different concept of business approach between nonprofit and profit organizations

Nonprofit organizations as providers of social capital and agents of change, they enhance community services that serve the common good and are directed to a part of the public in general, depending on whether organizations belong to the public or the third sector.

There are some basic concepts differences between sectors but nowadays we can argue that the marked differences are disappearing and sectors are becoming similar in certain ways. Still, we can observe some theoretical differences between profit and nonprofit organizations as follows:

\begin{tabular}{|l|l|l|}
\hline DIMENSIONS & PROFIT & NONPROFIT \\
\hline $\begin{array}{l}\text { STARTING POINT/ } \\
\text { MISSION }\end{array}$ & Profit & $\begin{array}{l}\text { Public } \\
\text { good/civil } \\
\text { society }\end{array}$ \\
\hline ORIENTATION & Consumer & $\begin{array}{l}\text { Individual } \\
\text { citizen }\end{array}$ \\
\hline CONCEPT & Economic & Social \\
\hline ARENA & Market & Society \\
\hline RESULTS & $\begin{array}{l}\text { Economics } \\
\text { measurable } \\
\text { quantitative social }\end{array}$ & $\begin{array}{l}\text { Social } \\
\text { economics } \\
\text { unmeasurable } \\
\text { qualitative }\end{array}$ \\
\hline
\end{tabular}

Tab.1. Differences between profit and nonprofit organizations through various dimensions

Management of nonprofit organization has strategical approach to planning, organizing, controlling and managing people, while taking into account the characteristics of volunteers, measuring results, managing and defining the organizational mission.

The excellence of nonprofit organizations is formed in a way that they properly manage the organization, taking care of their specific characteristics and improving their managerial skills.

\section{EXCELLENCE FOR NONPROFIT ORGANIZATIONS}

Striving for excellence is a key feature of modern business. The construction of products and high quality programs, the quality in cooperation with human resources become the basic requirements for the good management.

Searching for excellence in nonprofit organizations could be an encouragement to other organizations to follow the examples that promote quality and bring positive results. Nonprofit organizations are already well aware of the importance of motivation and productivity that creative professionals bring to organization-knowledge workers (Drucker, 2005: 42).

Outstanding nonprofit organizations share a common vision, says Fernsler (1999: 54):

(1) Employees are educated to achieve their maximum potential,

(2) There is a focus on the coaching staff,

(3)The organization focuses on the future,

(4) Practices and constructive criticism is encouraged, 
(5) All employees understand unique mission,

(6) Doing the right thing becomes standard in the organization,

(7) The organization remains focused on the mission,

(8) There is a clear financial responsibility,

(9) Success is celebrated.

Nonprofit organizations must be mission driven and good ones are promoters of knowledge, changes and healthy civil initiatives. Nonprofit organizations are: (1) Leaders of the learning organizations that might govern the economic activities in the future and (2) Carriers of innovation that can build a society, while providing valuable services and promote innovation (Drucker, 2005.).

The achievement of excellence in nonprofit organizations, and profit organization is extremely important because the key objectives must be clarified in order to achieve better efficiency and organizational improvement over period of time.

In the book "Forces for Good: The Six Practices of HighImpact Nonprofits" Grant \& Crutchfield (2007) talk about best practice through on the example of 12 nonprofit organizations that have made a significant social impact over a longer period of time. The authors emphasize that there are some kind of myths about the work of nonprofit organizations and critically explain the difficulty in giving clear and homogenous instructions on how to achieve success in this area, pointing, at the same time to certain pitfalls when proposing the final solution.

However, they provide an overview of the most common misconceptions or, as they call them, myths, concerning management excellence and the most successful nonprofit organizations and comment on them: Perfect management: Some of the organizations are not well managed in the traditional sense of the term and, although some management is necessary, it is not sufficient to explain how these organizations achieve such high level of impact; Brand-name awareness: For some of them, traditional mass marketing is a critical part of their impact strategy; for others, it's unimportant; A breakthrough new idea: Their success often depends more on how they implement a new idea or innovate as they execute than it does on the idea or model itself; Textbook mission statements: All these nonprofits are guided by compelling missions, visions, and shared values, but only a few of these groups spend time putting their mission statement on paper;

High ratings on conventional metrics: Top of Form; High positions: According to the standard measurements of success of this assessment does not need to show real achievement, so that they can be distinguished from those related to achieving a significant influence in society; Large budgets: Nonprofit organizations have different strategies of raising funds, so regardless their budget they have achieved a lot.

Successful organizations in the social sectors have common features (Crutchfield \& Grant, 2007: 46) point out through: (1) advocacy and service provision, nonprofit organization must not lose sight of the fact that, besides providing services, advocacy is also important because it increases their level of influence. (2) they make the market works, (3) inspire others, and (4) run changes in a way that they adapt, are ready to listen, learn and modify their behavior. In search for excellence nonprofit organizations are seen as learning organizations and leaders of driving innovations (Drucker, 2005).

It can be concluded that nonprofit organizations have a huge potential market. Their social mission must be clearly identified because if you combine the entrepreneurial spirit of innovation with good leadership you should achieve a significant social improvement in all important aspects of life.

\section{METHODOLOGY}

The aim of the research was to establish the differences of management implementation towards certain functions within sectors, i.e. nonprofit organizations and profit organization, The differences between management functions in profit and nonprofit organization as well as the differences in measurement and assessment of success among them were examined.

A descriptive one-time research on a national sample was conducted from spring until autumn 2010. The observed sample were 52 civil society organizations, 37 public companies and 27 profit companies; a total of 116 organizations, selected by the criteria of efficiency.

The results of this part of doctoral research indicate that there are minor differences in dimensions of policies and strategies and measuring results (best rated for-profit organizations). The dimensions of leadership, orientation towards society, people management, resource management and information best rated for organizations in civil sector show real examples of excellence.

There is a need of significant progress in all management functions, especially control and planning in all public organizations. Finally, all type of observed organizations need serious but fresh management approach that requires a lot of learning and improvement in all areas of management.

\section{CONCLUSION}

Nonprofit organizations are the ones based on certain values. Their aim is the realization of social objectives and their organizational culture must support the development of whole society. Persistence in achieving better results will contribute to greater effectiveness of the organization, which paves the way to be recognized as contributing to positive social change.

Nonprofit organizations have to develop strong management that can lead the organization through the uncertainty of the contemporary environment. Nonprofit organizations need to achieve excellence in its mission in order to justify their existence and make a difference in this world, whether in education, health, welfare, civil rights, or for other activities that have significant social impact.

In the end, concluding remarks can be made through the following dilemma: Will the future voluntary sector become pool of knowledge, innovation and human resources? Could the concept of knowledge management in conjunction with the altruism of the civil sector strengthen the cohesion of the whole society and set a new paradigm of global development?

Since the excellence of nonprofit organizations comes from devotion to the mission of nonprofit organization, could that nonprofit concept be applied to organizations in public and profit sectors? Could nonprofit organizations be leaders of future changes in Croatia, assuming dramatic and innovative concepts of work and life?

\section{REFERENCES}

Drucker, P. (2005), Najvažnije o menadžmentu, M.E.P., Zagreb Fernsler, T. (1999), What makes an organization excellent, Nonprofit World, 17(3): 53-54.

Lenkowsky, L. (2005), Drucker's contributions to Nonprofit Management, Business week online, $\mathrm{xx}(\mathrm{xx})$ : $\mathrm{xx}-\mathrm{xx}$.

Grant, H. M.; Crutchfield, L. R. (2007), Creating High Impact Nonprofits, Standford Social innovation Review, Standford: Jossey-Bass

Marić, I. (2011), Specifics of the functions of management of Nonprofit organization, Doctoral thesis, Faculty of Economics and Business, pp. 43., Zagreb

Wiijkström, F. (2009), Civil society, Working papers nonprofit management, Doctoral seminar - Brussels 